\title{
APPLICATION OF FEDERAL PROBATION TO CONVICTS SERVING CONSECUTIVE SENTENCES *
}

Probation is judicial supervision and guidance substituted for a period of imprisonment. ${ }^{1}$ The Federal Probation Act ${ }^{2}$ is uniformly interpreted to permit United States district courts to grant probation only if the sentence of imprisonment has not started. ${ }^{3}$ When several consecutive sentences are imposed on separate counts or indictments, it is settled that probation on some of the terms may be ordered to follow imprisonment on others if the probation decree precedes incarceration. ${ }^{4}$ However, conflict has arisen concerning the authority of district courts to grant probation in place of uncommenced terms of consecutive sentences once service of the initial term has started. This

*Phillips v. United States, 212 F.2d 327 (Sth Cir. 1954).

1. Parole and pardon are other major release procedures. Federal parole powers are vested in a presidentially appointed Parole Board which can release a prisoner after service of one-third of the total period of his sentences or fifteen years of a life sentence. 36 STAT. 819 (1910), as amended, 18 U.S.C. \& 4201 et seq. (1952). Both parolees and probationers are supervised by the Probation Officer. 46 STAT. 503 (1930), as amended, 18 U.S.C. $\$ 3655$ (1952). See Meyer, A Half Century of Federal Probation and Parole, $42 \mathrm{~J}$. Clind. L. \& CRIminology 707, 710 (1952). Under U.S. Const. Art. II, $\$ 2$, the president may release the duly convicted by use of the pardoning power. For discussion of the operation of probation, parole, and pardon see Glueck, Probation and Crimtival. Justice (1933); 2 U.S. Dep't of Justice, Survey of Release Procedures (1939); 3 id.; 4 id.; U.S. NAtional Commission on Law Observance and Enforcement, Report on Penal Institu. tions, Probation and Parole (1931).

2. 43 Stat. 1259 (1925), as amended, 18 U.S.C. $\$ 3651$ (1952), provides: "Upon entering a judgment of conviction of any offense not punishable by death or life imprisonment, any court having jurisdiction to try offenses against the United States, except in the District of Columbia, when satisfied that the ends of justice and the best interests of the public as well as the defendant will be served thereby, may suspend the imposition or exccution of sentence and place the defendant on probation for such period and upon such terms and conditions as the court deems best."

This legislation filled the vacuum created by Ex Parte United States, 242 U.S. 27 (1916), which held that federal trial courts had no authority to suspend scntences indefinitely. Formerly, the courts had exercised probation powers on the basis of their inherent authority. Miller v. United States, 41 App. D.C. 52 (Ct. App. 1913); United States v. Gilbert, 25 Fed. Cas. 1318, No. 15,205 (C.C.N.D. Ohio 1873); United States v. Blaisdell, 24 Fed. Cas. 1162, No. 14,608 (S.D.N.Y. 1869). See also 28 J. Carm. L. \& CRIMINology 141 (1937).

3. E.g., Pernatto v. United States, 107 F.2d 372 (3d Cir. 1939); United States v. Weiss, 28 F. Supp. 598 (E.D. Pa. 1939). See also United States v. Murray, 275 U.S. 347 (1928), holding that where the defendant has started scrvice of a given sentence, probation cannot be substituted for part of that term. The Supreme Court said that this holding was not inconsistent with Ackerson v. United States, 15 F.2d 268 (2d Cir. 1926) (probation may be ordered after the conviction has been appealed and the court term at which the sentence was imposed has ended), or Evans v. District Judge, 12 F.2d 64 (6th Cir. 1926) (district courts may grant probation at any time before the execution of the sentence is begun).

4. Frad v. Kelly, 302 U.S. 312 (1937); Cosman v. United States, 303 U.S. 617 (1938). 
conflict is significant because of the frequency with which defendants are charged and convicted on several counts or indictments."

In the recent case of Phillips v. United States, ${ }^{6}$ the Eighth Circuit held that a district court was powerless to grant probation after the first of consecutive sentences had begun. Phillips had been sentenced to five consecutive prison terms on five counts of an indictment. ${ }^{7}$ While serving the sentence imposed on the third count, he petitioned the district court to place him on probation at the end of that term. ${ }^{8}$ The district court decided that it had no power to grant the petition.9 The Eighth Circuit affirmed, relying on the Supreme Court's first interpretation of the Federal Probation Act in United States $v$. Murray. ${ }^{10}$ That case held probation to be inapplicable after service of a sentence had started. The Murray decision was partially grounded upon the view that probation was designed to save only the unhardened offender from the contaminating influence of prison. ${ }^{11}$ Moreover, the Supreme Court regarded parole as the appropriate form of clemency for the imprisoned convict, and therefore concluded that the power to extend probation anytime during the sentence would conflict with the Executive's authority under the Parole Act. ${ }^{12}$ Although Murray involved only a single sentence, the Eighth Circuit felt that it controlled Phillips because the consquences of imprisonment in terms of hardening influence and overlapping jurisdiction were the same in both cases. ${ }^{13}$ Thus the Eighth Circuit equated consecutive sentences with a single sentence for purposes of the probation power. ${ }^{14}$

5. The widespread practice of charging one offense in different ways is noted in 9 Cyc. of Fed. Procedure \$ 4119 (2d ed. 1943). United States v. Howell, 65 Fed. 402, 408 (N.D. Cal. 1895), speaks of the use of three counts for one offense as being in conformity with the practice of criminal pleading. Mfoore v. United States, 2SS Fed. 249, 250 (E.D.N.Y. 1923), indicates the desirability of the well settled practice of charging the same offense in several ways.

6. 212 F.2d 327 (Sth Cir. 1954). According to Communication to the Yale Law Journal from Rufus D. MicLean, Chief, Administrative Regulations Section, Criminal Division, United States Department of Justice, dated October 28,1954 , on file in Yale Law Library, the Supreme Court refused to grant certiorari in this case because a timely application was not made.

7. Phillips v. United States, 212 F.2d 327, 329 (Sth Cir. 1954).

8. Ibid.

9. Ibid.

10. 275 U.S. 347 (1928).

11. United States v. MLurray, 275 U.S. 347, 357 (1928).

12. Ibid. Conflict between parole and pardon authorities is sharply presented in Phillips v. United States, 212 F.2d 327, 329 (Sth Cir. 1954), where the district court recommended that Phillips be paroled and the Parole Board rejected his applization.

13. Phillips v. United States, 212 F.2d 327 (Sth Cir. 1954). Although the argument relating to the inappropriateness of probation for the hardened criminal is given less extensive treatment than the contention relating to overlap of probation and parole, it comes to the surface with the court's statement that probation "is discipline under sugervision, without incarceration, and is intended for those offenders who can, with safety to the public, be left at large after conviction ...." Id. at 334 .

14. Id. at 335. The United States District Court for the District of Mlaryland agreed with the Phillips decision in the case of United States v. Mann, decided on August 19, 
Kirk $v$. United States ${ }^{15}$ exemplifies the rejection of the Phillips cloctrine by the Ninth and Tenth Circuits. ${ }^{10}$ In Kirk the Ninth Circuit recognized the Murray limitation, but reasoned that while a convict is serving the first of consecutive sentences, he is not serving the others. ${ }^{17}$ Therefore, it concluded that a district court may suspend uncommenced consecutive sentences, since a sentence may be suspended anytime before it is begun. ${ }^{18}$ Similar reasoning in reaching the same conclusion was employed by the New York courts in interpreting the state probation law upon which the federal statute was apparently modeled. ${ }^{19}$

1954, but as yet unreported. Communication to the Yale LAw Journal from Rufus D. McLean, Chief, Administrative Regulations Section, Criminal Division, United States Department of Justice, dated October 28, 1954, on file in Yale Law Library. By way of dictum, that court came to the same conclusion in United States v. Stern, 123 F. Supp. 118, 125 (D. Md. 1954). And a recent decision by the District Court for the Northern District of Illinois concurred with the Phillips holding. United States v. Soeder, 120 F. Supp. 594 (N.D. Ill. 1954). Two earlier lower court cases had come to the same conclusion. United States v. Durkin, 63 F. Supp. 570 (N.D. Ill. 1945) ; Mouse v. United States, 14 F.2d 202 (D. Kan. 1926).

15. 185 F.2d 185 (9th Cir. 1950).

16. For the Tenth Circuit position, see White v. Steigleder, 37 F.2d 858 (10th Cir. 1930), where probation was approved as a substitute for a prison term on seven counts following imprisonment for one year on the first count. The United States contcnded that the defendant had served four months on the first term before release on a bond to appeal, and that such service prevented suspension of the second term; however, the record contained no information that the defendant had been imprisoncd. The court held that even if the defendant had served four months on the first sentence, the probation order on the second term was valid because "[c]learly, sentence had not begun under the counts affected by the probation order." Id. at 860 . In Kelley v. United States, 209 F.2d 638 (10th Cir. 1954), the Tenth Circuit held that district courts have power to grant probation under similar circumstances. There, the defendant was sentenced to a prison term to commence upon the expiration of a sentence in the Federal Reformatory. Ten months after the district court sentence was imposed, but before the reformatory term had ended, Kelley petitioned the district court to substitute probation for its sentence. The district court held it had no power to grant the petition and the Tenth Circuit reversed.

The Second Circuit approved the application of probation in a situation highly analagous to Kirk, Steigleder, and Kelley in United States $c . x$ rel. Edelson v. Thompson, 175 F.2d 140 (2d Cir. 1949). While Edelson was serving eighteen months imposed by the district court for the Southern District of New York, he received an additional sentence by the District Court for the Middle District of Pennsylvania. Approsimatcly five months later, before the first sentence had terminated, the Middle District of Pennsylvania Court substituted probation for its sentence.

17. Kirk v. United States, 185 F.2d 185, 187 (9th Cir. 1950). The court cited MeNally v. Hill, 293 U.S. 131 (1934), which held that for purposes of habeas corpus application, a prisoner serving one of consecutive sentences is not serving the athers. And United States v. Soeder, 120 F. Supp. 594, 595 (N.D. Ill. 1954), conceded that "a prisoner serving the first of several consecutive sentences is not serving the other sentences," whilc denying the power of the district court to substitute probation after the first of consecutive sentences has started.

18. See note 3 supra.

19. People v. Thuna, 266 App. Div. 223, 41 N.Y.S.2d 857 (2d Dep't 1943), reversing on other grounds, 178 Misc. 427, 34 N.Y.S.2d 1001 (County Ct. 1942). This case 
The Plitlips interpretation of the Probation Act is supported by the view of the purpose of probation which prevailed at the time of the Act's passage.23 Probation was generally conceived to be a means of keeping the unhardened offender away from prison, ${ }^{21}$ while parole was considered the appropriate relief for those in jail. ${ }^{22}$ Thus, Congress probably intended that probation be used only for criminals who had not been imprisoned. 23 The .IIurray opinion articulated this view, but conceded that the language of the statute was capable of "wider construction." 24

interprets N.Y. PENAL LAw, §218S which provides: "The Court . . may . . . (1) suspend sentence, or (2) ... impose sentence and suspend the execution of the judgment. In either such case he [the court] may place the defendant on probation ... . Provided, however, that the imprisonment directed by the judgment, shall not be suspended or interrupted after such imprisonment shall have commenced." The Federal Probation Law contains no express limitation such as that in the last quoted sentence of the New: York statute, although United States v. Murray, 275 U.S. 347 (1928), read a similar restriction into the Act. See text at note 3 supra.

For an indication that this statute was the model for the Federal law, see United States v. Antinori, 59 F.2d 171, 172 (5th Cir. 1932).

20. This view has been characterized in the following way: "Probation is not, but parole is, preceded by imprisonment .... For a judge to prescribe imprisonment as a condition of probation is for him to turn probation into parole and thus infringe upon the prerogative of the executive." See Warner, Some Legal Problems Raised By Prabation, a chapter in Glueck, Probation and Crmarnal Justice 35 (1933). See also 2 U.S. Dep't of Justice, Survey of Release Procenures 2 (1939).

21. Glueck, Probation and Criminal Justice 4 (1933); 4 U.S. Dep'r of Justice, Surtey of Release Procedures 1. (1939).

22. See authorities cited note 21 supra.

23. In 1920 hearings before the House Judiciary Committee on a proposed probation law, a brief presented by the National Probation Association defined probation as "the method by which the court disciplines and seeks to reform certain offenders without subjecting them to imprisonment" Hearings before Committe on the Judiciory on H.R. 340 , 1111, 1112, and 12036, 66th Cong., 2d Sess. 101 (1920). See also similar testimony of Representative John E. Raker before the same Committee. Id. at 141.

Testimony before the Senate Judiciary Subcommittee considering a probation law, included the following categorization of probation: "[P]robation, of course, aims to avoid the prison taint ...." Hearings before Subcommiltee of the Commitfee on the Indiciary on S. 1042 and 1729, ESth Cong., 1st Sess. 18 (1924).

24. United States v. MIurray, 275 U.S. 347, 358 (1928). Natural construction of the wording of the district courts' probation power, see note 2 supro, suggests that they were given extensive authority. The statute does not contain any intimation that these powers must be used within any given time or before any special event. For example, a court may imprison the adjudged criminal for a violation of the terms of probation occuring afier the probation period had expired. And it may exercise such power during a period equal to the longest possible sentence which could have been imposed, regardless of the length of the actual sentence. Mason v. Zerbst, 74 F.2d 920 (10th Cir. 1935). And in Burns v. United States, 287 U.S. 216 (1932), commitment to the exceutive for imprisonment did not stop the court from exercising its probation powers to revolic probation granted on a consecutive sentence which was to start after the prison term the convict was then serving.

The Supreme Court in Roberts v. United States, 320 U.S. 264, 268 (1943), points up the extensive Congressional deliberation leading up to the Act's broad statement of 
The modern theory of probation, reflected in subsequent "wider construction" and in the revision of the Federal Probation Act, buttresses the Kirk doctrine. Two analogous Supreme Court cases decided after Murray reject the concepts that parole and probation are mutually exclusive and that probation is applicable only to novice criminals. ${ }^{20}$ In Frad $v$. Kelly, ${ }^{20}$ where defendant received consecutive sentences on separate indictments, the Supreme Court permitted substituting probation for the second term before imprisonment on the first sentence had started. ${ }^{27}$ Cosman $v$. United States ${ }^{28}$ extended Supreme Court approval to probation in a situation identical with Frad except that the consecutive sentences were imposed on different counts of the same indictment. ${ }^{20}$ Thus the defendants in these cases were contaminated with imprisonment and subject to the jurisdiction of the Parole Board when probation became effective. ${ }^{30}$ Congress endorsed Frad and Cosman in the 1948 revision of the Federal Probation Act by providing that "[p]robation may be limited to one or more counts or indictments ...."31 This history of federal probation subsequent to Murray points toward a rejection of the Phillips doctrine.

judicial power to suspend sentences. It seems doubtful that careful consideration could have resulted in such sweeping statutory language unless Congress intended to grant broad power.

This natural construction of the Probation Act receives support from Nix v. James, 7 F.2d 590, 592 (9th Cir. 1925), which held it to be a remedial statute, and, hence, entitled to liberal construction. See also Scalia v. United States, 62 F.2d 220 (1st Cir. 1932); United States $e x$ rel. Tomasello v. Smith, 50 F. Supp. 464 (E.D. Pa. 1943).

25. Frad v. Kelly, 302 U.S. 312 (1937); Cosman v. United States, 303 U.S. 617 (1938).

26. 302 U.S. 312 (1937)

27. Frad v. Kelly, 302 U.S. 312, 315 (1937).

28. 303 U.S. 617 (1938).

29. Cosman v. United States, 303 U.S. 617 (1938). The facts of this case are unavailable from the memorandum decisions handed down by the Supreme Court and Second Circuit, 94 F.2d 1020 (2d Cir. 1938), and the district court decision is unreported. However, the facts are set out in Remer v. Regan, 104 F.2d 704, 705n.1 (9th Cir. 1939). In Cosman the Second Circuit held that imprisonment and probation could not be granted on separate counts of the same indictment; it cited United States v. Greenhaus, 85 F.2d 116 (2d Cir. 1936), which was precisely in point. The Supreme Court reversed on the authority of Frad v. Kelly, 302 U.S. 312 (1937). In United States ex. rel. Edelson v. Thompson, 175 F.2d 140 (2d. Cir. 1949), the Second Circuit conceded that the Greenhaus case had been overruled by Cosman v. United States. The District Court for the Northern District of Illinois was apparently unaware of this judicial history when it strongly relied on Greenhaus in reaching its decision in United States v. Soeder, 120 F. Supp. 594 (N.D. Ill. 1954). See note 14 supra.

30. In most situations where imprisonment and probation are imposed under separate counts or indictments, parole could effect at least the same reduction. For example in Cosman v. United States, 303 U.S. 617 (1938), defendant was sentenced to fourteen months on the first count and two years on the other three counts with the execution of the two year term suspended. See note 29 supra. Assuming that the two year term had not been suspended, the Parole Board could have released him in less than thirteen months, since it can release a prisoner after service of one-third of his total sentence. See note 1 supra.

31. 62 StAT. 842 (1948), 18 U.S.C. \& 3651 (1952). The Revisers' notes following 
Policy considerations support allowing district courts to substitute probation for uncommenced terms after the first of consecutive sentences has started. Courts equipped with this power could better discharge their sentencing duties in cases where they are uncertain as to the appropriate term. ${ }^{32}$ The courts" ability to fit the punishment to the criminal would be improved, since highly valuable information about the defendant's character and rehabilitation progress could be secured from his prison record..$^{33}$ If a court could postpone final determination of sentence by imposing consecutive sentences, ${ }^{34}$ the benefits of

U.S.C. \& 3651 (1952) indicate that the second paragraph of that section which contains the noted change "reflects exactly the practice of the Federal courts."

32. Allowing a court to substitute probation for uncommenced terms of consecutive sentences after the first has been started is the only practical way under the Probation Act in which a convict's prison record can be used as a sentencing aid in cases where the proper sentence is doubtful. The other possible method open to the court is to imprison on some counts or indictments and substitute probation for others with the expectation of revoking the probation order if the defendant's prison record indieates the desirability of his serving the second term. A probation order cannot be revoled except for cause at a hearing. Escoe v. Zerbst, 295 U.S. 490 (1935). It is questionable whether additional knowledge gained about the defendant's character or his rehabilitation record would be sufficient cause for revocation of probation. It is doubtiul that district courts would choose to rely on being able to equate those factors with cause or on the possibility of the convict's committing a minor act on which probation revocation could be rationalized. This alternative is undesirable since the convict would have no confidence in a probation order susceptible of revocation for reasons which would scem capricious to him. This device should be restricted to the case where the court is convinced of the desirability of placing the defendant on probation at the end of the term. Revocation would then result only from relatively major misconduct, rather than simply from the defendant's failure to make appreciable rehabilitation progress.

33. The benefits of using a criminal's prison record as a sentencing aid were stressed by the Consmittree on Punishament for Crnie, Refort Jum. Cosf. Cossar. on PusisuaIENT For CRnIE 2 (1942). Composed of Judges John J. Parker, Learned Hand, Orie L. Phillips, John C. Collet, Carol C. Hincks, Bolitha J. Laws, and Paul J. McCormick, the Committee made the following proposal: When a trial judge believes a sentence should be longer than one year, the maximum term is to be imposed initially with authority in the judge to alter the sentence later. Id. at 1 . The Committee rejected a proposed indeterminate sentence law which would have length of imprisonment determined by an administrative board after study of the criminal's history. It was felt that judicial supremacy had to be maintained in the sentencing area to assure that individual rights are given the maximum of protection and to maintain public confidence in the administration of the criminal law. Id. at 8,28 .

For discussion of the indeterminate sentencing procedure for federal courts proposed in the Federal Corrections and Parole Improvement Bills, see Comment, 53 YaLE LJ. 773, 780-786 (1944). For discussion of the benefits of the indeterminate sentence, see Yankwich, Changing Concepts of Crime and Punishment, 32 Geo. L.J. 1 (1943). A contrary view is found in Webster, Evolution of Probation in American Law, 1 Burf. L. REv. 249, 257 (1952).

For discussion of the modern objective of making the punishment fit the criminal, rather than the crime, see Cohen, Moral Aspects of the Criminal Law, 49 Yale L.J. 987, 1019-22 (1940) ; McGuire and Holtzoff, The Problem of Sentenee in the crinainal Law, 20 B.U.L. REv. 423, 424 (1940).

34. There is some evidence that district courts are imposing consecutive sentences to keep control over the imprisoned convict so that his sentence may subsequently be 
clairvoyance could be attained through hindsight. In addition, harmony would be promoted between two primary objectives of sentencing, rehabilitation and deterrence ${ }^{35}$ While the publicity given heavy sentences promotes the policy of deterrence, such sentences may be opposed to the goal of rehabilitation..$^{30} \mathrm{By}$ enabling the court to impose a severe sentence on a number of counts or indictments and then to suspend all but the initial term before the first sentence is concluded, both rehabilitation and deterrence can be achieved. Headlines are made by long jail sentences, not by their suspension months later.

Increased district court probation power would add flexibility to release procedures by supplementing the authority of the Parole Board. The Parole Board can release a prisoner only after completion of one-third of his entire sentence. ${ }^{37}$ Thus, while completion of the first of consecutive sentences might not qualify the prisoner for parole, a court able to substitute probation for subsequent sentences could effect his release. And release even before the end of the first term might be possible if the court's probation order suspending subsequent sentences were issued during the term; for if the accomplished service were then greater than one-third of the total amended sentence, the Parole Board could effect immediate release.

Power to suspend uncommenced consecutive terms after the first sentence has started would also minimize the possibility of injustice or error in Parole Board action. Parole Board decisions may be colored by political or emotional

modified. Judge Collet in Phillips v. United States, 212 F.2d 327, 336 (8th Cir. 1954), states: "the practice has been widely followed of imposing separate sentences of imprisonment on separate counts or charges and then, in the light of developments later, suspending a subsequent sentence or sentences not yet commenced if such action is merited." In Communication to the YALE LAw Journal from Leon R. Yankwich, Chief Judge, United States District Court, Southern District of California, dated Oct. 11, 1954, on file in Yale Law Library, Judge Yankwich indicated that it is a matter of individual policy with judges in his court whether to use consecutive sentences as a means of keeping control over a defendant in order to retain the power to revise his sentence at a later date.

If the Supreme Court rejects the Kirk doctrine, an injustice will be clone to those defendants to whom district courts have given long terms in anticipation of later sentence reduction. And even if the Supreme Court takes no action and does not reject Kirk, prisoners in the Phillips Circuit sentenced by courts relying on the Kirl: doctrine will be unjustly treated. Thus, although the Supreme Court denied certiorari in Phillips because a timely petition was not made, see note 6 supra, the next case presenting the issue should receive Supreme Court consideration. This opportunity may be presented by United States v. Mann, supra note 14.

35. For discussion of the role of rehabilitation and deterrence in sentencing considerations, see Chandler, Later-Day Procedures in The Sentencing and Treatment of Offenders In The Federal Courts, 37 VA. L. Rev. 825, 829 (1951).

36. The judge's problem when confronted with violation of tax or selective service laws is presented in Chandler, supra note 35 , at 829 . Chandler states that a court often feels it necessary to impose a severe sentence as a deterrent to others, yet is convinced that such a sentence is not necessary to insure against the commission of a similar offense by the defendant.

37. See note 1. supra. 
considerations. ${ }^{38}$ A judicial officer could ordinarily be expected to be more objective. $^{39}$ And even if the court were frequently influenced by such factors, a prisoner would be more likely to receive an unbiased decision if afforded two opportunities. Moreover, the court often has a unique opportunity to judge the defendant's character and degree of guilt by evaluating the demeanor of the defendant and all witnesses. ${ }^{40}$ Supplementing the prison record with its trial impressions, the court is more likely than the Parole Board to determine the proper time for release.

Application of the Kirk doctrine need not result in harassment of district judges. This doctrine is rendered administratively feasible by its retention of the Murray limitation, ${ }^{41}$ which prohibits substitution of probation for part of a commenced sentence. ${ }^{42}$ In cases where the district court is certain as to the appropriate punishment, it could bar applications for probation by imposing a general sentence upon all counts of an indictment. ${ }^{43}$ And there is substantial reason to believe that a court could even impose a general sentence on separate indictments. ${ }^{44}$ Moreover, since district courts have wide discretion

38. The likelihood of a presidentially appointed board being influenced by political motives was noted by the Subcommittee on Sentencing Adult Offenders, Cosssirtee o:

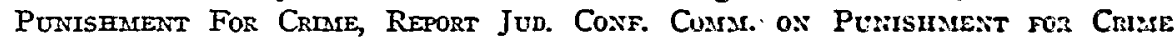
$27-8$ (1942). Without becoming involved in the merits of the Alger Hiss case, it may be postulated that many factors other than the standards set forth in the Parole .let were considered by the Board when Hiss' petition for parole was taken up. The Parole Act provides release may be granted if "there is a rcasonable probability that such prisoner will live and remain at liberty without violating the laws, and if in the opinion of the Board such release is not incompatible with the welfare of society . . . " 36 Stat. 819 (1910), as amended, is U.S.C. $\$ 4203$ (1952).

39. Report of the Subcommittee on Sentencing Adult Offenders to the Committer on Punishment For Crime, op. cit. supra note 38, at 27-8.

40. For discussion of the significance of demeanor of the defendant and vitnes:es, see 2 WigMIORE, EVIDENCE $\$ 274$ (2) and n.2 (3d ed. 1940); 3 id. $\$ 946$.

41. See text at note 17 supra.

42. United States v. MIurray, 275 U.S. 347 (1928). See text at notes 10-11 sufpro.

43. Barnes v. United States, 197 F.2d 271, 273 (8th Cir. 1952). The majority and dissenting opinion in Phillips apparently agree that a general sentence may be imposed on several counts and that such a sentence will bar applications for probation after the first part of the sentence has started. Phillips v. United States, 212 F.2d 327, 335, 337 (8th Cir. 1954).

44. While not completely lucid, Ex Parte De Bara, 179 U.S. 316 (1900), indicates that a general sentence may be imposed on several separate indictments. Convicted for use of the mails for fraudulent purposes on eleven indictments, De Bara reccived a single sentence of three years imprisonment. After serving eighteen months, he netitioned for a writ of habeas corpus, claiming that the statute set a limit of eighteen months imprisonment for offenses commited within a six month period. The Court rejected that argument, holding that the statute only limited the number of offenses chargeable on a single indictment and the maximum punishment for each offense. The statute provided that: "[t]he indictment ... may severally charge offenses to the number of thrce ... but the court thereupon shall give a single sentence...." The Court said that the sentence was not imposed on a single indictment. Hence, since the statute did not authorize a single sentence on several indictments and De Bara received a singie sentence on several indictments, this decision apparently approves the proposition that a general sentence can be imposed on several 
in dealing with probation petitions, ${ }^{45}$ they can avoid harassment and overwork. For example, the courts apparently can pass on probation applications without the defendant's presence, ${ }^{46}$ and their decision on the merits is not subject to appellate review. 47

Power to revise uncommenced consecutive terms after imprisonment on the first is a logical adjunct of judicial sentencing authority, since such modification constitutes determination of the ultimate sentence. The contention that this power is judicial usurpation of an executive function is oblivious not only to policy considerations but also to the nature and development of probation. ${ }^{48}$

indictments. But see United States ex rel. Chasteen v. Denemark, $138 \mathrm{~F} .2 \mathrm{~d}$ 289, 291 (7th Cir. 1943).

45. See Burns v. United States, 287 U.S. 216, 220 (1932) ; Gillespie v. Hunter, 159 F.21 410, 411 (10th Cir. 1947).

46. See Phillips v. United States, 212 F.2d 327, 337 (8th Cir. 1954) (dissenting apinion). There are no statutory requirements for giving a defendant a hearing on a probation application, and no cases have been discovered hoiding that this must be done.

47. United States v. White, 147 F.2d 603 (3rd Cir. 1945), held: "The action of the court in refusing to grant the privilege [probation] is accordingly not reviewable on appeal except possibly for arbitrary or capricious action on the part of the District Court which amounts to an abuse of discretion." See, also, United States v. Phillips, 212 F.2d 327, 337 (9th Cir. 1950) (dissenting opinion).

48. Objection to the overlap of probation and parole, referred to as judicial usurpation of an executive function in United States v. Durkin, 63 F. Supp. 570, 573 (N.D. IIl. 1945), has been the major argument of cases opposing the Kirk doctrine. See United States $v$. Murray, 275 U.S. 347, 356-7 (1928) ; Phillips v. United States, 212 F.2d 327, 333-4 (8th Cir. 1954) ; United States v. Soeder, 120 F. Supp. 594, 596 (N.D. Ill. 1954).

This argument sometimes degenerates into mere manipulation of labels. Sce United States v. Soeder, supra. Proponents of Kirk can also use labels for support. Sec United States v. Benz, 282 U.S. 304 (1931), where the Supreme Court held that the district court could reduce a sentence during the term it was imposed after the defendant lind been imprisoned. Faced with the argument that this was judicial usurpation of an exccutive function, the Court said: "The judicial power and the executive power over sentences are readily distinguishable. To render judgment is a judicial function. To carry the judgment into effect is an executive function. To cut short a sentence by an act of clemency is an exercise of executive power which abridges the enforcement of the judgment, but does not alter if qua judgment. To reduce a sentence by amendment alters the terms of the judgment itself and is a judicial act as much as the imposition of the sentence in the first instance." Id. at 311. 